\title{
Local Irritation of Isotonic Acetic Acid Solutions of the Rabbit M. vastus lateralis and Confirmation of the Injected Sites
}

\author{
Toshiaki OCHIAI, Kiyoshi MATSUMOTO, Kiyoshi SEKITA, \\ Osayuki UCHIDA, Yasushi KAWASAKI \\ and Tsuyoshi FURUYA

\begin{abstract}
Division of Toxicology, Biological Safety Research Center, National Institute of Hygienic Sciences, Kamiyoga 1-18-1, Setagaya-ku, Tokyo 158, Japan
\end{abstract}

(Received 7 December 1984 / Accepted 5 July 1985)

\begin{abstract}
One $\mathrm{ml}$ of $0.106 \%, 0.425 \%$ or $1.7 \%$ acetic acid (AA) solution, isotonic to physiological saline solution, was injected into the $M$. vastus lateralis of male Japanese white rabbits. Two, 7, 14 and 21 days after the injections, the rabbits were autopsied, and the removed muscles were observed macroscopically. After fixation with $10 \%$ neutral formalin, they were examined histologically. Hemorrhage and white degeneration of the muscles were grossly observed in $0.106 \%, 0.425 \%$ and $1.7 \% \mathrm{AA}$ at 2 days. These lesions disappeared at 7 days and thereafter in $0.106 \% \mathrm{AA}$, and at 14 days and thereafter, except for one animal, in $0.425 \% \mathrm{AA}$. In $1.7 \% \mathrm{AA}$, these lesions were observed until 21 days, but gross hemorrhage began to recover at 21 days. The size of the lesion, which was expressed as a product of the major axis ( $\mathrm{mm}$ ) and minor axis $(\mathrm{mm})$ of the lesion, showed reduction over time, especially in $1.7 \%$ AA. Histologically, swelling, necrosis and calcification of the muscle fibers and cell infiltration, hemorrhage and dilatation in the interstitium were observed after the injections of $0.106 \%, 0.425 \%$, and $1.7 \% \mathrm{AA}$. At 7,14 and 21 days, regeneration of the muscle fiber and fibrosis in the interstitium were observed. The injected sites were examined by injecting a chip of test-tube brush as a marker. In $20(83 \%)$ of 24 cases, it was ascertained that the markers were injected into the $M$. vastus lateralis. The markers were found in the $M$. vastus intermedius in 3 out of 4 other cases and in the intermuscular tissue between the $M$. vastus lateralis and M. tensor fasciae latae in one case.
\end{abstract}

等張酰酸溶液のウサギ外側広筋（M. vastus lateralis）に対する

局所障害性ならびにその投与部位の確認

落合敏秋・松本清司・関田清司

内田雄幸・川崎 靖・降矢 強

国立衛生試験所安全性生物試験研究センター毒性部 
所障害性に関する試験法」(案)(以下試験法と略す)が公 表された[11]。試験法は動物試験法, 溶血性試験法およ び細胞毒性試験法の 3 部より構成されている。動物試験 法は, ウサギの外側広筋または仙棘筋に被検注射剂なら びに対照液である生理食塩液，0.75\%酥酸打よび $6 \%$ 酢 酸を注射し，注射後 2 日目， 7 日目に筋肉を摘出し注射部 位の病変の程度を各対照液のそれと比較して, 被検注射 剂の局所障害性を 4 段階にグレード付けするものである。

しかしこの方法で各注射剂のグレード付けを行ったと ころ, 各研究所間でそのグレードに大きな違いの生じる ことが認められた[7]。一方, 赤石ら[1]は注射剂の浸透 圧は生体のそれに近いことが望ましいと述べている。し かしこの試験法では対照液の浸透圧について触れられて いない。そこで，浸透圧を生理食塩液を等張にした酢酸 溶液をウサギの外側広筋に注射してその局所障害性を調 べたので報告する。

なお，著者らは外側広筋への注射に際し，布巻き法[6] を用いてウサギを保定している。この方法で外側広筋に 注射できるか否かを調へるために，注射部位の確認に関 する実験も行った。

\section{材料および方法}

試料：生理食塩液 $(290 \mathrm{mOsm} / \mathrm{kg})$ と等張な $0.106 \%$, $0.425 \%$ および $1.7 \%$ 酶酸を用いた。試薬特級酶酸（和光 純薬工業)を局方注射用蒸留水 (山口製楽) で生理食塩 液と等張となるように $1.7 \%$ に稀釈し，さらに局方注射 用生理食塩液 (山口製薬) で希釈することにより生理 食塩液と 等張な所定の 濃度の酢酸溶液を 作成した。こ れらの溶液の浸透圧を Advanced D-II 型浸透圧計 (Advanced instruments, 米国) で測定したところ， $0.106 \% ; 296 \mathrm{mOsm} / \mathrm{kg}, 0.425 \% ; 298 \mathrm{mOsm} / \mathrm{kg}, 1.7$ $\% ; 301 \mathrm{mOsm} / \mathrm{kg}$ であった。

動物：雄日本白色種ウサギ（体重 $2.5 \sim 3.5 \mathrm{~kg}$, 船橋 農場産）を用いた。

ウサギを 1 群12匹からなる 3 群に分け,それぞれ0.106 \%酢酸群， $0.425 \%$ 酢酸群および $1.7 \%$ 酶酸群とした。

注射：注射には $1 \mathrm{ml}$ ディスポーザブル注射器および 23ゲージディスポーザブル注射針（テルモ）を用いた。 注射針の刺入の深さを一定にするために注射針の先端か ら $1 \mathrm{~cm}$ のころにストッパーをつけた (Fig. 1)。

注射は，発熱性物質試験法で用いられる布巻き法 [6] により背臥位に固定し，外側広筋に相当する部位に行っ た。アルコール綿で清拭した後，注射針を皮厧に対して

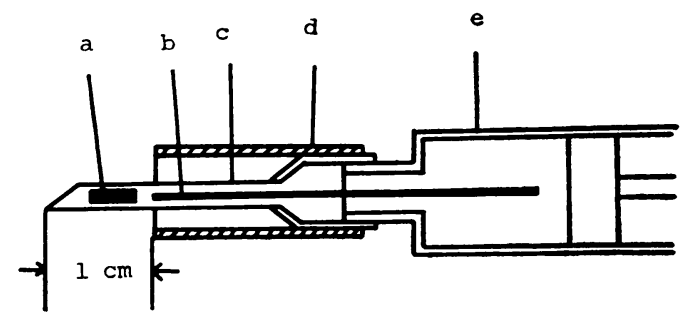

a : $5 \mathrm{~mm}$ test-tube-brush chip (marker)

$\mathrm{b}$ : mandrel ( $45 \mathrm{~mm}$ )

c : 23 gauge injection needle

d : stopper

e : $1 \mathrm{ml}$ syringe

Fig. 1. Illustration of chip-injection method

垂直に立て $1 \mathrm{~cm}$ 刺入した。

注射部位を確認するための実験では，Fig. 1 に示す ようにマーカーとして試験管ブラシの毛先を約 $5 \mathrm{~mm} に$ 切ったものを注射針の先に入れ，注射器に入れた $1 / 4$ 皮 下針のマンドリン $(45 \mathrm{~mm})$ で注射液と共に組織内に押 し出した。

右外側広筋に試料である酢酸溶液を，また左側には注 射用生理食塩液をそれぞれ $1 \mathrm{ml} 5 \sim 10$ 秒かけて注射し た。

観察：注射後 $2 ， 7,14$ おび21日目に各群 3 匹のウサ ギをペントバルビタール Na 麻酔下 $(25 \mathrm{mg} / \mathrm{kg}$, i. v.) で頸動脈より放血致死させた後, 左右外側広筋を摘出し た。摘出筋は表面の肉眼的観察を行った後, 筋肉を縦方 向に切開し，割面を肉眼的に観察した。その後，10\%中 性ホルマリン液に固定し，パラフィン包埋および薄切の 後へマトキシリンーエオジン染色を施し, 組織学的検査 に供した。

注射部位の確認の実験では， 1 群 6 匹からなる 2 群の ウサギの右外側広筋に $0.425 \%$ 酢酸あるいは1.7\%酶酸を， また左側に生理食塩液を各々マーカーと共に $1 \mathrm{ml}$ 注射 し，その後 2 日目，14日目に剖検してマーカーの見られ た部位を記録した。

\section{成 楼}

\section{1）注射部位の確認}

2 日目および14日目の合計 24 例のうち20例の外側広筋 にマーカーを認めた。その他はマーカーが中間広筋内に あったもの 3 例扣よび大腿筋膜張筋と外側広筋の間に発 見されたもの1例であった。

マーカーのみられた外側広筋のうち，生理食塩液を注 


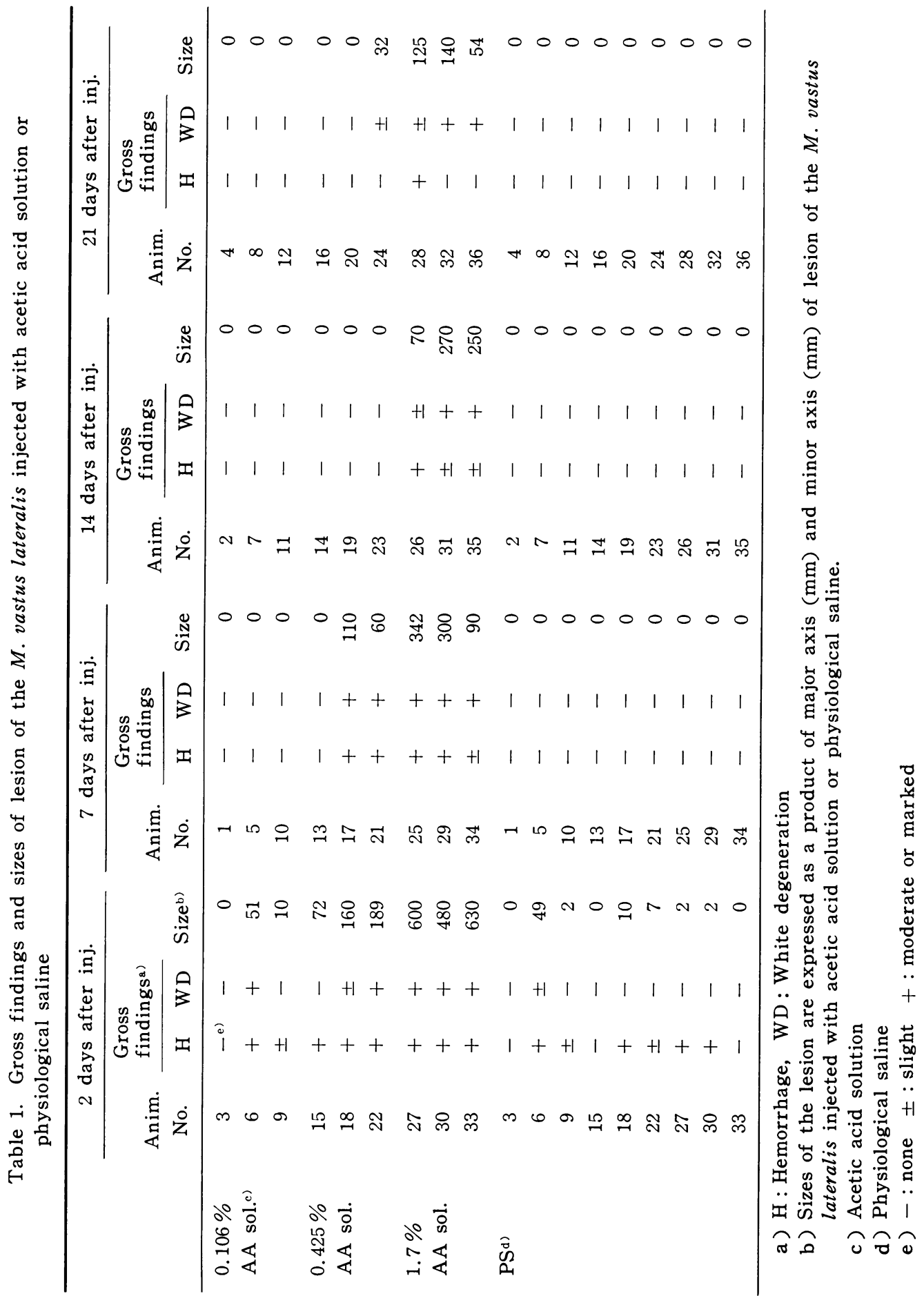


射した例では，2 日目では平均（土標準偏差） $33 \pm 8$ $\left(\mathrm{mm}^{2}, \mathrm{n}=3\right)$ の広がりをもつ出血がみられ，その中心 部にマーカーが確認された。14日目では, 肉眼的には変 化はみられなかった。0.425\%酢酸を注射した筋肉では 2 日目で $173 \pm 35(n=2), 14$ 日目で $25 \pm 31(n=3)$ の 出血がみられ, 出血の中央部には調理肉棣を呈す白変 化[9]がみられた。1.7\%酶酸では 2 日目で $236 \pm 52(n=$ 3)，また14日目では $112 \pm 28(n=3)$ の出血がみられ， 中央部は白変化を呈していた。そして各酢酸とも変化部 の中央付近にマーカーである毛先が発見された。

2) 等張酢酸溶液の局所障害性

(1) 肉眼的所見

Table 1 に各動物の肉眼的所見と出血あるいは白変 化からなる変化部の長径と短径の積を示した。

生理食塩液では 2 日目で 9 例中 6 例に出血がみられ， そのうち 1 例では白変化が認められた。7日目以後は肉 眼的に変化は認められなかった。0.106\%酢酸では， 2 日目に执いて 2 例に軽度ないし中等度の出血がみられ， うち 1 例は出血の中央部に白変化が観察された。7日目 以後変化は観察されなかった。 $0.425 \%$ 酢酸では 2 日目 および 7 日目で出血および白変化が認められたが，14日 目では変化はなく，21日目では 1 例に軽度の白変化が認 められた。1.7\% 酢酸では, いずれの観察時期において も白変化を認め (Fig. 2)，特に 2 日目では， 1 例に白 変化の中央部が褐色を呈しているのが観察された。また 出血は，14日目および21日目で各々 2 例で軽度になるか あるいは消失していた。

Table 2 に变化部の長径と短径の積を 各群の平均值 で示した。0.425\%抽よび1.7\%酢酸では日数の経過と共 に低值に推移した。

(2) 組織学的所見
Table 3 に組織学的所見を示した。

$0.106 \%$ 酶酸では， 2 日目扣よび 7 日目で笳線維の極 軽度ないし軽度の筋線維の膨化および間質の抎張ならび に円形細胞浸潤が観察されたが，14日目および21日目で は変化はなかった。 $0.425 \%$ 酢酸では 2 日目および 7 日 目で筋線維の膨化および壊死がみられるが，14日目では この両変化はなく, 21 日目では 1 例に軽度の壊死が認め られた。7 日目以後 1 例に筋線維の再生像を認めた。間 質には 2 日目および 7 日目で円形細胞あるいは好酸性細 胞の浸潤, 出血および間質の抎張などがみられ， 7 日目 以後正常組織と変性壊死組織との境界部に結合組織線維 の増殖 (Fig. 3) が各観察時期で 2 ないし 3 例みられる。 $1.7 \%$ 酶酸では, 全例に筋線維の膨化, 壊死 (Fig. 4) が みられ, さらに 7 日目以後筋線維の再生像が観察された (Fig. 5)。間質には, 細胞浸潤, 出血扰よび抎張がみら れた。さらに $0.425 \%$ 酢酸と同様に 7 日目以後変性壊死 した筋線維と正常組織との境界部に結合組織線維の増殖 がみられた。これらの線維は Azan-Mallory 染色によ り青染された (Fig. 6)。

生理食塩液では, 2 日目に筋線維の膨化, 壊死および 間質の細胞浸潤などがみられたが，7日目以後は変化は 認められなかった。

\section{考察}

等張酢酸溶液のウサギ外側広筋への影響を調べるため に，浸透圧を生理食塩液と等張となるように調整した $0.106 \% ， 0.425 \%$ 扣よび $1.7 \%$ 酢酸を各々 $1 \mathrm{ml}$ 注射して 注射後 $2,7,14$ および21日目に剖検した。

その結果， $0.106 \%$ 酢酸は， 2 日目で 3 例中 2 例に出 血，1例に白変化を認めるが，7日目では変化はみられ

Table 2. Average sizes of gross lesion of the $M$. vastus lateralis injected with acetic acid solution or physiological saline

\begin{tabular}{lcccc}
\hline & \multicolumn{4}{c}{ Days after injection } \\
\cline { 2 - 5 } & 2 & 7 & 14 & 21 \\
\hline $0.106 \%$ acetic acid sol. & $\left.20 \pm 27(3)^{\mathbf{a}}\right)$ & $0(3)$ & $0(3)$ & $0(3)$ \\
$0.425 \%$ acetic acid sol. & $140 \pm 61(3)$ & $57 \pm 55(3)$ & $0(3)$ & $11 \pm 18(3)$ \\
$1.7 \%$ acetic acid sol. & $570 \pm 79(3)$ & $244 \pm 135(3)$ & $197 \pm 110(3)$ & $106 \pm 46(3)$ \\
Physiological saline & $8 \pm 16(9)$ & $0(9)$ & $0(9)$ & $0(9)$ \\
\hline
\end{tabular}

a) Average sizes of gross lesion are expressed as mean $\pm \mathrm{S}$. D. of a product of major axis $(\mathrm{mm})$ and minor axis ( $\mathrm{mm})$ of gross lesion of the $M$. vastus lateralis injected with acetic acid solution or physiological saline in 3 or 9 animals.

Figures in parentheses are the number of animals examined. 
Table 3. Histological findings of the $M$. vastus lateralis injected with acetic acid solution or physiological saline

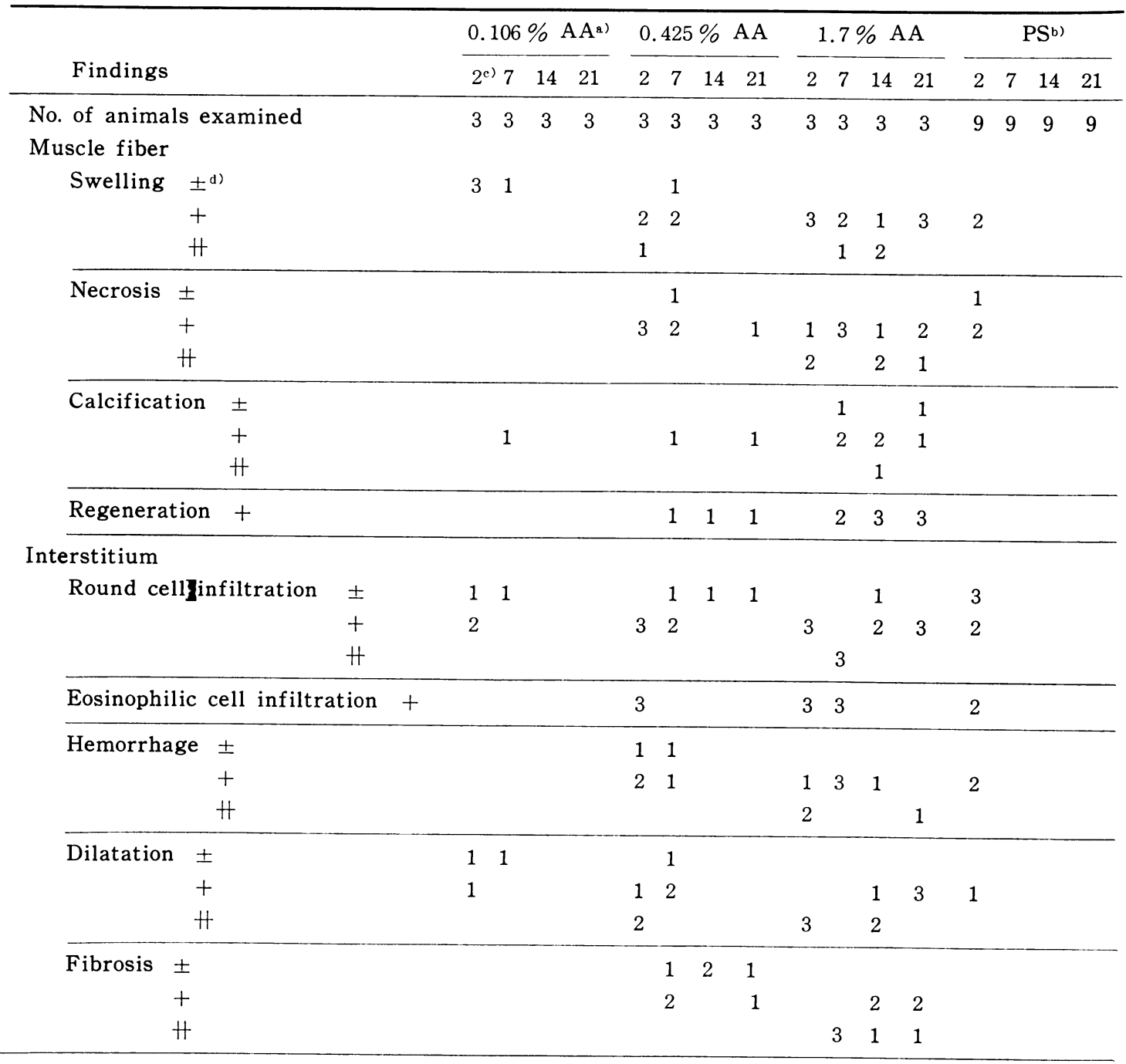

a) acetic acid solution b) Physiological saline c) Days after injection

b) \pm : very slight + : slight $H$ : moderate

なかった。組織学的には 2 日目および 7 日目で筋線維に 軽度の変性を認めたが，壊死はみられなかった。0.425 \%酢酸では 2 日目打よび 7 日目で白変化と出血がみられ たが，14日目以後では 1 例を除いてこれらの変化は消失 していた。組織学的には，肉眼所見と一致して筋線維の 壞死や間質の出血は14日目で消失していた。

$1.7 \%$ 酷酸は21日目まで白変化を認めるが，出血は 14 日目で軽度となり，21日目では 2 例で認めることができ なかった。これらのことは組織学的所見とも一致して,
21日目では筋線維の壊死がみられるが，出血は軽度ある いは消失していた。

さらに $0.425 \% ， 1.7 \%$ 酥酸では 7 日目以後，筋線維の 再生像あるいは間質の線維增殖が観察された。間質にみ られた線維は Azan-Mallory 染色に青染することより， 膠原線維であることがわかった。

これらの肉眼的拉よび組織学的変化の程度 (变化部の 大きさも含む）あるいは回復時期に明らかな用量関係が みられ，2 日目に観察された肉眼的拉よび組織学的変化 
は濃度および注射後の経過日数に依存して縮小あるいは 回復に向うものと思われた。今回認められた組織学的変 化は種々の薬剂を筋肉注射した時にみられる変化 $[2$ 〜 $4,10,12]$ と同様のものであった。

府川ら [4]は，生理食塩液で稀釈した $0.047 〜 96 \mathrm{v} / \mathrm{v}$ \%酢酸溶液注射時の肉眼的変化には，暗赤色調あるいは 鮮紅色調の変色部分をもつ壊死領域がみられ，日数の経 過と共にその変色部分は消失し，7 日目以後では壊死領 域のみが残存することを報告し, 変化には濃度による質 的差異は認められず，障害領域の大きさと治凂日数にの み差があったと述べており, 今回の実験結果によく一致 していた。また濃度の概ね等しい酢酸では回復の時期も 府川らの結果とほぼ一致していた。

一方, 礒部ら $[5]$ は， $6 \%$ 酶酸水溶液をウサギに筋肉 注射したところ, 注射後 1 日目から 7 日目まで肉眼的変 化に回復がみられなかったことを報告している。また， 蒸留水， $0.106 \%$ および $0.425 \%$ 酢酸水溶液を注射して, その後 2 日目， 7 日目にに剖検したところ, 蒸留水と同 程度の変化がみられ, 用量関係および回復の傾向は認め られなかった (未発表)。これらのことより, 注射剂の 局所障害性試験の対照液として酢酸を用いる場合は, 酢 酸を生理食塩液で稀釈するか, または生理食塩液と等張 にすることが重要と思われた。

今回の方法での外側広筋への注射の成功率は $83 \%(20$ /24例）であった。これはラットで報告されている大腿 四頭筋に筋肉注射した時の成功率 (81\%) [8]とほぼ同

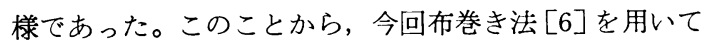
ウサギを保定して注射したことは適切であったと思われ る。しかし, 成功率を上げるためには, 保定, 特に後肢 の保持方法が大切であると思われる [8]ので，この点に ついて後改良を加えたい。

\section{要 約}

生理食塩液を等張となるように調整した $0.106 \%, 0$. $425 \%$ および $1.7 \%$ 酢酸の各 $1 \mathrm{ml}$ 雄日本白色種ウサギの 外側広筋に注射し, 注射後 $2,7,14$ および21日目に屠殺 剖検した。摘出筋は肉眼的観察の後, $10 \%$ 中性ホルマリ ン液に固定し組織学的検查に供した。筋肉の出血および 白変化が 注射後 2 日目で $0.106 \% ， 0.425 \%$ およ゙ $1.7 \%$ 酢酸に肉眼的に観察された。これらの変化は $0.106 \%$ 酢 酸では注射後 7 日目以後では観察されず，0.425\%酢酸 では14日目以後，1例を除いて観察されなかった。1.7 \%酢酸では21日目までこれらの変化がみられたが, 出血
の程度は21日目で回復の傾向にあった。変化部の長径と 短径の積で示される変化部の大きさは時間の経過と共に 縮小した。特に $1.7 \%$ 酢酸で明らかであった。組織学的 には, 筋線維の膨化, 壊死掞よび石灭化ならびに間質の 細胞浸潤，出血，抎張が $0.106 \% ， 0.425 \%$ および $1.7 \%$ 酢酸で観察された。注射後 7，14および21日目で筋線維 の再生掞よび間質の結合組織線維の増殖が， $0.425 \%$, $1.7 \%$ 酢酸で観察された。試験管ブラシの毛先をマーカ 一として注入する方法で注射部位の確認を行ったとこ ろ，注射した24例中20例 $(83 \%)$ でマーカーが外側広筋 に注入されていることがわかった。その他の 4 例は中間 広筋に注入されているもの 3 例, 外側広筋と大腿筋膜張 筋の筋間にみられたもの1例であった。

稿を終るにあたり，注射部位の確恝法について御教示 を賜わった武田薬品工業株式会社中央研究所新谷茂博土 ならびに衘校閲を賜った国立衛生試験所 毒性部長戸部 満寿夫博土に深甚の謝意を表わす。また実験に協力を 惜しまなかった毒性部臼井章夫君に感謝する。本研究は 厚生科学研究費の援助により行った。なお, 研究の一部 は第30回実験動物談話会 (1983, 東京) に拉いて発表し た。

\section{文 献}

［1］赤石英・押田茂実・高橋由美子（1974）。薬剤に関する医 療事故について. 月刊薬事, 16, 901 909.

[2] 赤塚謙一・橋本孝雄・竹内 幸一・竹内みどり・神田 実喜 男 (1979).ブタ前立腺エキス (Rabaveron $囚)$ の局所刺 激性試験 ウサギへの筋肉内注射における形態学的検討. 応用薬理, 18, 181 190.

[3] Cioc, M., and von Schilling, B. (1965). Changes in muscular tissue produced by injection of some known drugs. Toxicol. Appl. Pharmacol., 7, 179 189.

［4］府川和永・伊東義彦・三崎則幸・坂東和良 (1975)。剌激 性試験法に関する研究 (第 1 報) 酢酸筋注時の障害組織回 復試験. 薬学雑誌, 95, 1307 1316.

［5］礒部 竹雄・小田島 寿子・竹内 祐幸・宇高 奎二 (1981). Flunitrazepam のウサギに対する局所皮膚ならびに筋肉 剌激性試験. 応用薬理, 22, 47 55.

［6] 刚米達夫・石館守三・長瀬雄三監修 (1976). 発熱性物質 試験法. 第九改正日本薬局方解説書, B-176, 日本公定書 協会編, 広川書店, 東京.

[ 7] 厚生省薬務局安全課資料, 1983.

[8] 信永 利馬・高橋 和明 - 岡本 道生 - 若藤 清匡 - 川西広明 (1974). 注射による投与とその問題点 (ラットを例にあげ て). 免疫実験操作法 B, pp. 713 729, 日本免疫学会編, 日本免疫学会, 金沢.

[9] 新谷 茂・ 川路尚徳 - 米田友彦 - 山崎実 - 中村桃吉 - 梶原 挃 (1963).クロモマイシン $\mathrm{A}_{3}$ の局所障害に関する実験 的研究. 武田研究所年報, 22, 227 253.

[10］内田寛 (1976). 筋注製剤の溶血性, 笳肉障害性およびそ 
の回復性について，応用薬理， 12,95 113.

[11] 薬事日報, 5818号 (1979年 1月23日). 薬事日報社.

[12] Yamazaki, M., Maeda, M., Tsukamoto, T., Tsukamoto, T., Iwanaga, M., and Shintani, S. (1972).
Observation on the local tissue toxicity of Enramycin in experimental animals. J. Takeda Res. Lab. (Takeda Kenkyu Sho Hō), 31, 263 281.

\section{Explanation of figures}

Fig. 2. Gross appearence of the muscle (right) 7 days after the injection of $1.7 \%$ AA solution. White degeneration, surrounded with hemorrhage, is seen on the cut surface of the muscle. No macroscopical lesion is seen in the another muscle injected with physiological saline.

Fig. 3. A micrograph of the muscle 7 days after the injection of $0.425 \%$ AA solution. Connective tissue prolifiration is seen between the normal and necrotic tissue (H-E stain, $\times 40)$.

Fig. 4. A micrograph of the muscle 2 days after the injection of $1.7 \%$ AA solution.
Marked degeneration and necrosis of the muscle fiber, cell infiltration and hemorrhage are seen $(\mathrm{H}-\mathrm{E}$ stain, $\times 100)$.

Fig. 5. A micrograph of the muscle 21 days after the injection of $1.7 \% \mathrm{AA}$ solution. Regeneration of the muscle fiber is seen as giant cells with connective tissue prolifiration, cell infiltration and hemorrhage ( $\mathrm{H}-\mathrm{E}$ stain, $\times 100)$.

Fig. 6. A micrograph of the muscle 7 days after the injection of $1.7 \%$ AA solution showing prolifiration of collagenous fibers in the interstitium (Azan-Mallory stain, $\times 100)$. 

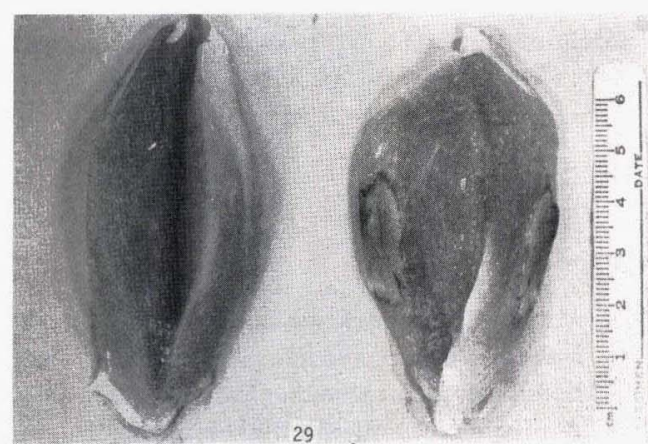

Fig. 2

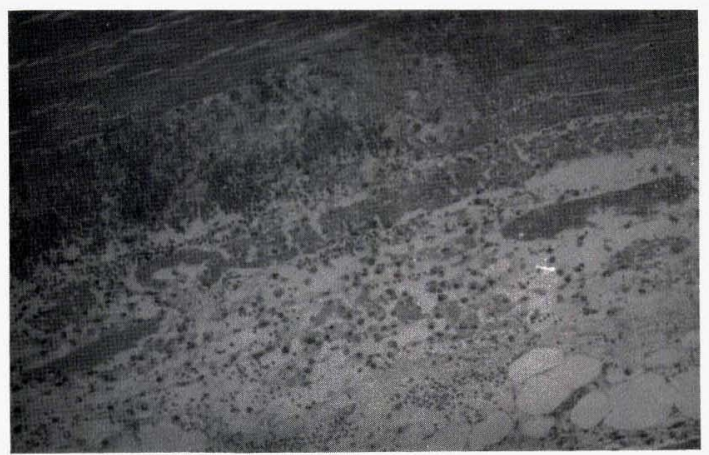

Fig. 4

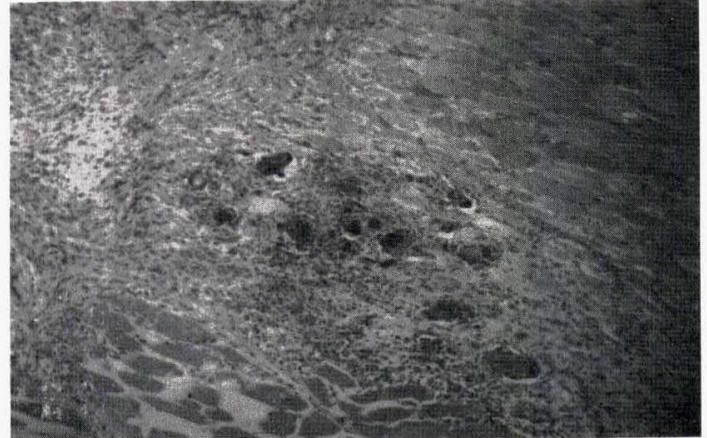

Fig. 3

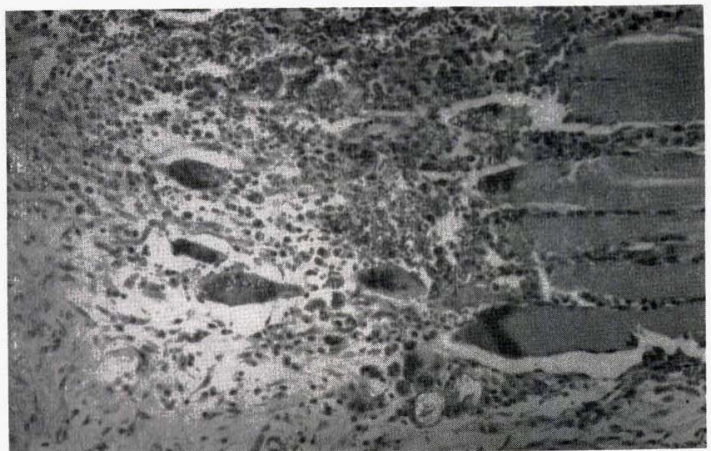

Fig. 5

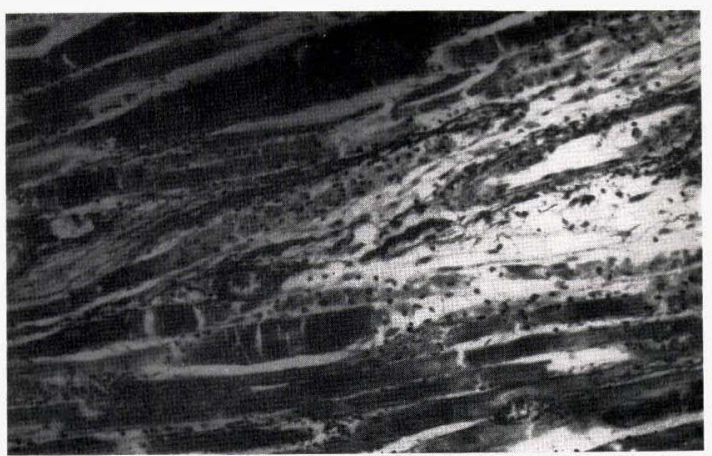

Fig. 6 